Research Papers

\title{
Evidence Suggesting that Ivory-billed Woodpeckers (Campephilus principalis) Exist in Florida
}

\section{Données suggérant la présence du Pic à bec ivoire (Campephilus principalis) en Floride (États-Unis)}

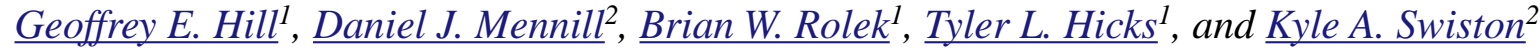

\begin{abstract}
The Ivory-billed Woodpecker (Campephilus principalis) disappeared from the forests of southeastern North America in the early $20^{\text {th }}$ Century and for more than 50 years has been widely considered extinct. On 21 May 2005, we detected a bird that we identified as an Ivory-billed Woodpecker in the mature swamp forest along the Choctawhatchee River in the panhandle of Florida. During a subsequent year of research, members of our small search team observed birds that we identified as Ivory-billed Woodpeckers on 14 occasions. We heard sounds that matched descriptions of Ivory-billed Woodpecker acoustic signals on 41 occasions. We recorded 99 putative double knocks and 210 putative kent calls. We located cavities in the size range reported for Ivory-billed Woodpeckers and larger than those of Pileated Woodpeckers (Dryocopus pileatus) that have been reported in the literature or that we measured in Alabama. We documented unique foraging signs consistent with the feeding behavior of Ivory-billed Woodpeckers. Our evidence suggests that Ivory-billed Woodpeckers may be present in the forests along the Choctawhatchee River and warrants an expanded search of this bottomland forest habitat.
\end{abstract}

RÉSUMÉ. Le Pic à bec ivoire (Campephilus principalis) est disparu des forêts du sud-est de l'Amérique du Nord au début du $20^{\mathrm{e}}$ siècle et pendant plus de 50 ans, cette espèce a été considérée comme étant éteinte. Le 21 mai 2005, nous avons détecté un individu que nous avons identifié comme étant un Pic à bec ivoire dans une forêt marécageuse à maturité le long de la rivière Choctawhatchee, dans l'extrême nord-ouest de la Floride (États-Unis). Durant l'année qui a suivi, les membres de notre petite équipe de recherche ont observé des individus identifiés comme étant des Pics à bec ivoire à 14 occasions. Nous avons entendu des sons qui correspondent aux descriptions des signaux acoustiques du Pic à bec ivoire à 41 occasions. Nous avons enregistré 99 tambourinages qui pourraient être des double knocks et 210 cris qui ressemblent au kent émis par ce pic. Nous avons trouvé des cavités de taille semblable à celles rapportées pour le Pic à bec ivoire et de taille plus grande que celles rapportées pour le Grand Pic (Dryocopus pileatus) tant dans la littérature que dans notre aire d'étude en Alabama. Nous avons également photographié des excavations qui correspondent à celles qui seraient associées à la quête de nourriture chez le Pic à bec ivoire. Ces données suggèrent que le Pic à bec ivoire pourrait être présent dans les forêts situées le long de la rivière Choctawhatchee et justifient une recherche plus approfondie dans ce secteur de forêt marécageuse.

Key Words: avian conservation; bottomland hardwood forest; Campephilus principalis; Choctawhatchee River; Ivory-billed Woodpecker

\footnotetext{
${ }^{1}$ Auburn University, ${ }^{2}$ University of Windsor
}

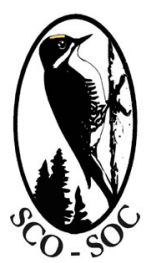

Sponsored by the Society of Canadian Ornithologists and Bird Studies Canada Parrainée par la Société des ornithologistes du Canada et Etudes d'oiseaux Canada

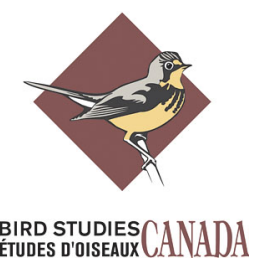




\section{INTRODUCTION}

The Ivory-billed Woodpecker (Campephilus principalis) was once resident in the mature bottomland forests of southeastern North America from east Texas to Florida and the Carolinas along the Gulf and Atlantic Coasts and north in the Mississippi River Valley to southern Missouri (Jackson 2002; 2006a). Populations were greatly diminished and isolated by the cutting of swamp forests in the late $19^{\text {th }}$ and early $20^{\text {th }}$ centuries, and collectors shot many of the remaining birds (Tanner 1942, Jackson 2002, 2006a). The last welldocumented Ivory-billed Woodpecker lived in the Singer Tract in northeast Louisiana before the last of that virgin forest was logged in 1944 (Jackson 2002, 2006a). A second, disjunct population of Ivory-billed Woodpeckers may have persisted in the mountains of Cuba until 1988, but that population was pronounced extinct by the end of the $20^{\text {th }}$ century (Lammertink 1995). Over the last 60 years, a few sight records in the continental United States have suggested the presence of Ivory-billed Woodpeckers, particularly in Louisiana (Gallagher 2005), but most bird authorities concurred that the Ivory-billed Woodpecker was likely extinct by the latter part of the $20^{\text {th }}$ century (American Ornithologists' Union 1983). In 2005, a video purporting to show an Ivory-billed Woodpecker along the Cache River in Arkansas was published (Fitzpatrick et al. 2005), but whether or not the indistinct image captured on this video is an Ivorybilled Woodpecker remains contentious (Jackson 2006b, Sibley et al. 2006, Fitzpatrick et al. 2006a, $2006 \mathrm{~b}$ ). The failure of a massive search of the forests of eastern Arkansas from 2004 to 2006 to reliably relocate Ivory-billed Woodpeckers suggests that no population of Ivory-billed Woodpeckers persists in that area (Fitzpatrick et al. 2006b).

On 21 May 2005, GEH, TLH, and BWR detected a bird that appeared to be an Ivory-billed Woodpecker in a mature swamp forest along the Choctawhatchee River north of the town of Bruce in the Florida panhandle. The Choctawhatchee River and its major tributaries flow through more than 20000 ha of mature, seasonally flooded forest. Baldcypress (Taxodium distichum) was selectively cut from this watershed in the early $20^{\text {th }}$ century, but extensive stands of oak (Quercus spp.), other hardwoods, and scattered huge baldcypress remained uncut. From December 2005 to May 2006 we searched for Ivorybilled Woodpeckers in an approximately 500-ha plot of forest surrounding the location of our initial detection. Two of us (BWR and KAS) camped in the area throughout this period, and the other researchers visited periodically. We moved through the area daily in kayaks and by foot, looking and listening for Ivory-billed Woodpeckers. We carried small video cameras to record images and sounds. In addition, we used seven automated listening stations to make 24-h digital sound recordings throughout our study area.

\section{METHODS}

\section{Sound Recordings}

We erected seven automated listening stations consisting of Sennheiser ME-62 omni-directional microphones with K6 power modules and Marantz PMD-670 solid-state digital recorders powered by sealed lead-acid batteries. Microphones were housed in rain guards made of polyvinyl chloride (PVC) tubing and attached to the top of 3-m wooden stakes using $30-\mathrm{cm}$ shelf brackets. Stakes were attached to small trees so that sound was recorded from all directions. All components were camouflaged with spray paint. To facilitate $24-\mathrm{h}$ recordings, sounds were recorded as MP3 files at $44.1 \mathrm{kHz}, 16$ bit, $160 \mathrm{kbps}$ onto Hitachi 3GB microdrive cards. Memory cards and batteries were changed daily.

Field recordings were split into consecutive 60-min recordings and converted to AIF or WAV format using "Audition" (Adobe, San Jose, California). Files were then scanned using "Syrinx-PC" sound analysis software (J. Burt, Seattle, Washington), which allowed us to visualize all recordings minute by minute, to compare field recordings with spectrograms of historical Ivory-billed Woodpecker "kent" calls from 1935, and to directly annotate sounds of interest. For all double knocks, we measured the delay between the two knocks (start time of the first knock to the start time of the second knock) using the time cursors of Syrinx-PC (resolution $0.001 \mathrm{~s}$ ). We measured relative amplitude of knocks using the Maximum RMS Power feature of Audition (background noise below $400 \mathrm{~Hz}$ was filtered as necessary using the FFT filter function of Audition). 


\section{Cavities}

To measure the numerous large cavities in the 500ha study plot, we used a retractable $12-\mathrm{m}$ pole to raise a ruler next to cavity entrances and then took a digital photograph of each entrance and ruler. We photographed 131 cavities clearly enough and with a scale in the photo so that we could quantify cavity entrance size. We used "ImageJ" software (U.S. National Institutes of Health) to calculate the vertical and horizontal dimensions of each photographed cavity entrance. Photographing cavities at an angle from below is likely to distort their size, but the distortion should result in an underestimate of the vertical dimension, thus making our measurements of cavity size conservative.

In July and August 2006, we searched for large cavities in forests in Lee and Macon counties, Alabama, approximately $200 \mathrm{~km}$ north of our Ivorybilled Woodpecker study area. Lee and Macon counties have abundant Pileated Woodpeckers (Dryocopus pileatus), but no Ivory-billed Woodpeckers or signs of Ivory-billed Woodpeckers have been reported in these counties in more than 60 years of intensive ornithological work by faculty and graduate students at nearby Auburn University.

\section{Foraging Sign}

We quantified bark adhesion with a Cabela's Advanced Angler's $50 \mathrm{lb}$ Digital Scale graduated at $0.01 \mathrm{~kg}$ increments with a maximum capacity of 30 kg (Cabela's Inc., Sidney, Nebraska). We attached an L-shaped bracket made of steel (a picturehanging bracket) to the hook on the scale. We pushed the lower part of the bracket under the bark immediately next to a woodpecker feeding mark and recorded the force required to lift the bark by $1 \mathrm{~cm}$. We took three bark adhesion measurements per tree, and used the mean adhesion per tree in comparisons. We did not restrict our measurements of bark adhesion to the best putative Ivory-billed Woodpecker feeding trees nor to what we thought was "fresh" feeding sign. Rather, we chose patches of forest with signs of woodpecker foraging and measured the adhesion of bark to all trees $>5 \mathrm{~cm}$ in diameter that showed obvious signs of woodpecker foraging, without regard to whether it appeared fresh or old. Our goal was to quantify the full range of adhesion strengths of bark next to woodpecker foraging sign in different forested regions.
We measured bark adhesion within our 500-ha Ivory-billed Woodpecker study area in Florida, and in three seasonally flooded bottomland hardwood forests along Saugahatchee, Choctafaula, and Uphapee Creeks in Lee and Macon counties, Alabama, approximately $200 \mathrm{~km}$ north of the Florida site. All four of these sites support high densities of Pileated Woodpeckers, but we have detected no Ivory-billed Woodpeckers during intensive bird surveys of the three sites north of the Choctawhatchee over the past 4 years. The three northern sites supported mature bottomland hardwood forests with a history of disturbance and tree-species composition that was largely similar to that of the forests along the Choctawhatchee River. The northern creek bottomlands were narrower and less extensive than the vast swamps along the Choctawhatchee River. At all sites, common trees were water hickory (Carya aquatica), spruce pine (Pinus glabra), sweetgum (Liquidambar styraciflua), red maple (Acer rubrum), overcup oak (Quercus lyrata), and swamp chestnut oak (Quercus michauxii). There was much more water tupelo (Nyssa aquatica) and baldcypress in the Florida site compared with the Alabama sites, but these trees were uncommon feeding substrates for woodpeckers. We did not attempt to quantify forest composition at any of these sites.

\section{RESULTS}

\section{Human Detections}

On 14 occasions, we sighted birds well enough to observe the diagnostic shape, plumage pattern, or flight behavior characteristics of Ivory-billed Woodpeckers (Appendix 1: table S1). On two of these occasions, we observed two birds together. In each of these encounters, observers who had abundant experience with Pileated Woodpeckers and other southern swamp birds identified field marks that were characteristic of Ivory-billed Woodpeckers, such as white trailing edges on black wings, non-undulating loon-like flight with stiff wingbeats, and white lines running from the neck down the back (see Appendix 1: table S1).

Members of our research team heard sounds matching the distinctive double knock and kent call of Ivory-billed Woodpeckers, including several bouts of repeated double knocks or kent calls, 41 times between May 2005 and April 2006 (Appendix 1: table S2). Seven of 12 visitors to the study site 
between May 2005 and April 2006 heard sounds consistent with Ivory-billed Woodpecker kent calls or double knocks. We recorded nine putative double knocks and five putative kent calls with hand-held video cameras, including consecutive double knocks that appeared to be given by two different birds.

\section{Sound Recordings}

Seven automated listening stations spaced approximately $500 \mathrm{~m}$ apart collected $11419 \mathrm{~h}$ of audio recordings between 5 January and 23 April 2006. From these recordings and the audio recordings from hand-held video cameras, we isolated 99 putative double knocks and 210 putative kent calls (Fig. 1; Appendix 1: table S3). Many of these recordings are faint because we used omnidirectional microphones to record birds that were seldom near the listening stations. However, our recordings of both putative kent calls and putative double knocks match historical descriptions of Ivory-billed Woodpecker acoustic signals. Members of our search team never played kent calls or attempted to mimic double knocks, and we never encountered another birdwatcher in the area. We are confident that the sounds that we recorded were not made by a human attempting to mimic an Ivorybilled Woodpecker.

Allen and Kellogg recorded kent calls from Ivorybilled Woodpeckers in Louisiana in 1935 (Tanner 1942). These calls were recorded from a breeding pair at their nest and the vocalizing birds appeared to have been agitated by the humans making the recordings. Thus, any comparisons between our recordings and the Allen and Kellogg recordings must be treated cautiously because of likely differences in the context in which the calls were produced. Nevertheless, the putative kent calls that we recorded share similarities in fine structure to the Allen and Kellogg recordings, being composed of short, harmonically rich syllables. The fundamental frequency and first two harmonics of the kent calls recorded by Allen and Kellogg have frequencies of $632 \pm 24 \mathrm{~Hz}, 1264 \pm 50 \mathrm{~Hz}$, and 1891 $\pm 68 \mathrm{~Hz}($ mean \pm SD for $n=31$ calls; historical kent recordings were measured from the Cornell Laboratory of Ornithology website; http://www.bir ds.cornell.edu/ivory/). Although our faint recordings made detailed frequency measurements difficult for many recorded calls, we found similar frequencies for the fundamental frequency and first two harmonics of putative kent calls recorded near the Choctawhatchee River: $748 \pm 102 \mathrm{~Hz}(n=161), 1443$ $\pm 220 \mathrm{~Hz}(n=184)$, and $2144 \pm 334 \mathrm{~Hz}(n=172$; lower frequency harmonics were more difficult to measure in more distant recordings). Putative kent calls that we recorded in Florida in $2006(0.21 \pm 0.08$ sec, $n=210$ ) were slightly longer than calls recorded at the nest by Allen and Kellogg in Louisiana in $1935(0.11 \pm 0.01 \mathrm{sec}, n=31)$. Our recordings of putative kent calls match Tanner's (1942) description of Ivory-billed Woodpecker kent calls, "with the vowel sound dominant and sounding between the note of a clarinet or saxophone mouthpiece and a tinny trumpet."

Of the 210 putative kent calls we recorded, 132 were recorded as single, isolated calls. The remaining 78 calls were recorded in 31 bouts, where calls were repeated two to five times (average number of calls per bout $=2.50 \pm 0.77$ ) with an average inter-kent interval of 4.6 seconds. Putative kent calls were recorded at all times of day from 0704 (early morning) to $1747 \mathrm{~h}$ (late afternoon, just before sunset).

Sounds that resemble Ivory-billed Woodpecker kent calls are produced by Red-breasted Nuthatches (Sitta canadensis), White-breasted Nuthatches (Sitta carolinensis), gray squirrels (Sciurus carolinensis), and Blue Jays (Cyanocitta cristata) (Jackson 2002, Tanner 1942), and may also be produced by Great Blue Herons (Ardea herodias) (R. Charif, pers. comm.). Neither species of nuthatch was detected at our site, either by experienced human observers or on our remote sound recordings. Great Blue Herons are common along the Choctawhatchee River, but their occasionally kent-like calls could be distinguished because they were followed in sequence by repeats of their more common squawk-like calls. Gray squirrels, which are plentiful throughout our study site and produce a "chuck" call with harmonic structure similar to the Ivory-billed Woodpecker's kent call, could be distinguished on the basis of a drawn-out squeal that follows the "chuck." Blue Jays have immense vocabularies of vocalizations (Tarvin and Woolfenden 1999) and may be able to produce notes that closely resemble Ivory-billed Woodpecker kent calls (Charif et al. 2005). Such vocalizations are atypical sounds for Blue Jays and should not be their exclusive vocalizations. If Blue Jays were the source of our putative kent calls, then kent calls should be commonly associated with more familiar Blue Jay vocalizations. However, 
Fig. 1. Sound spectrograms of putative Ivory-billed Woodpecker recordings and comparison sounds. Sound spectrograms of putative Ivory-billed Woodpecker double knocks (A-F) and kent calls (E, F) recorded along the Choctawhatchee River, Florida in 2005 and 2006. Spectrograms of the double knock of a Pale-billed Woodpecker (D) and a recording of a kent call of an Ivory-billed Woodpecker made in 1935 (G) are shown for comparison. Sound files available through online supporting information.

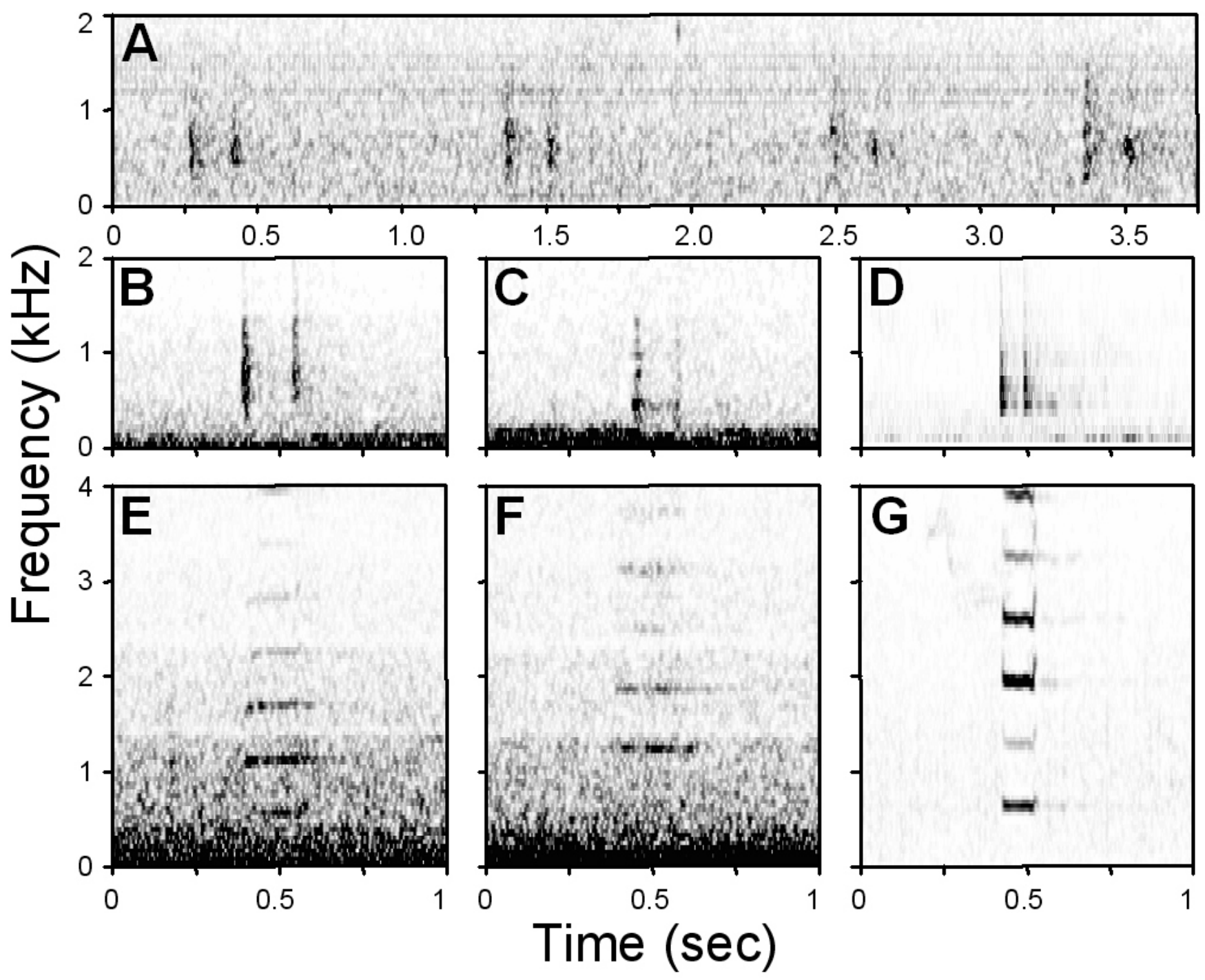

none of the 210 putative kent calls recorded by our listening stations were associated with any known Blue Jay vocalizations. Between December and March, Blue Jays were absent from the core study area and were detected only at the edges of the swamp next to pine (Pinus spp.) stands. Blue Jays were not detected within the core study area either by experienced human observers or by our listening stations until the end of March, at which time both humans and listening stations recorded the appearance of Blue Jays, especially at the periphery of the study area. Numerous putative kent calls were heard by human observers and recorded by listening stations in February and early March, when no Blue Jays were present. 
No recording of the Ivory-billed Woodpecker's double knock exists for comparison with our recordings from the Choctawhatchee River. Tanner (1942) describes the double knock as a "hard, double rap, BAM-bam, the second note sounding like an immediate echo of the first." The timing of the putative double knocks that we recorded is consistent with this description of two raps in direct succession: the average delay from the start of the first knock to the start of the second knock was 0.115 \pm 0.003 seconds $(n=99)$. In $45 \%$ of our putative double knocks, the first knock was louder than the second, matching Tanner's description (Jackson 2002). A louder first knock may be a common double-knock pattern among Campephilus woodpeckers (Jackson 2002), but amplitude of Campephilus double knocks has not been investigated systematically. Our recordings of Pale-billed Woodpeckers (Campephilus guatemalensis) from Costa Rica reveal double knocks with both loud/soft patterns and soft/loud patterns (D.J.M., unpublished data).

The putative double knocks that we recorded show tremendous variation in tone, which likely reflects variation in the substrate upon which they were produced. A recording of nine successive double knocks produced by a single Pale-billed Woodpecker in Costa Rica demonstrates the variation in the quality of double knock sounds that can be produced by one individual: all nine of these double knocks were produced by the same bird on different parts of one tree (supporting information sound file: Appendix 11; recorded by D.J.M. with a Sennheiser MKH70 directional shotgun microphone and a Marantz PMD660 solid state digital recorder on 12 May 2006 in Santa Rosa National Park, Costa Rica).

Of the 99 putative double knocks that we recorded, 69 were recorded as isolated sounds. The remaining 30 were recorded in ten bouts, wherein double knocks were repeated two to nine times (average number of double knocks per bout $=3.0 \pm 0.7$ ). Double knocks were recorded at all times of day from 0542 (twilight, shortly before sunrise) to 1720 (just before sunset).

Twice we recorded series of putative double knocks that appear to have been produced by two different individuals. The first recording has nine double knocks (recorded 25 December 2005 at 0730 with a hand-held video camera); the first two double knocks are distant, the intermediate five double knocks are markedly louder, and the final two double knocks are distant. TLH, who recorded these double knocks, and BWR, who stood next to him, thought the sounds were coming from two birds in front of them in the forest, but out of view. The second recording has three double knocks (recorded 20 January 2006 at 0927 at an automated listening station); the last two double knocks in the file are given in direct succession and at different intensities.

On 11 days, we recorded both putative kent calls and putative double knocks at a single listening station or at adjacent listening stations separated by approximately $500 \mathrm{~m}$. January 12: 1 kent call and 5 double knocks; January 22: 3 kent calls and 5 double knocks; February 6: 10 kent calls and 2 double knocks; February 9: 4 kent calls and 1 double knock; February 10: 3 kent calls and 1 double knock; March 2: 1 kent call and 1 double knock; March 13: 1 kent call and 1 double knock; March 20: 1 kent call and 7 double knocks; March 25: 5 kent calls and 1 double knock; March 26: 7 kent calls and 3 double knocks; April 10: 23 kent calls and 1 double knock (Appendix 1, Fig. S1).

\section{Cavities}

Ivory-billed Woodpeckers were reported to excavate cavities with larger entrances than any other woodpecker that lived north of Mexico (Jackson 2002, Tanner 1942). We found many large cavities in the forests along the Choctawhatchee River (Fig. 2). The vertical diameter of the entrance holes for 20 of the cavities we measured fell in the size range of active Ivory-billed Woodpecker nest cavities measured in the Singer Tract in Louisiana in the 1930s (12.7 cm and greater) (Tanner 1942), and the vertical diameter for 33 of the cavities we measured exceeded the maximum published height for the cavity entrance holes of Pileated Woodpeckers (12.0 cm) (Bull and Jackson 1995). The horizontal diameter of the entrance holes for 67 cavities fell in the range of Ivory-billed Woodpecker cavities (10.2 cm and wider) (Tanner 1942) and the horizontal diameter for 98 cavities exceeded the maximum reported width for the cavity entrance holes of Pileated Woodpeckers $(9 \mathrm{~cm})$ (Bull and Jackson 1995) (Fig. 3).

We compared size of cavity entrances along the Choctawhatchee River to the largest cavities we could find in Lee and Macon counties, Alabama, 
Fig. 2. Examples of the many large cavities found within the 500-ha study area. (A) A cavity that appeared very fresh when found in December 2005 in a live water tupelo (Nyssa aquatica). (B) Two cavities in a live water tupelo. The top cavity is larger and fresher than the bottom cavity, which has shrunk in size as scar tissue has grown around the lip. (C) A cavity in large (127 cm at cavity height) baldcypress (Taxodium distichum). (D) Cavity in a live water tupelo. (E, F) Cavities in the decayed soft wood in the tops of dead sweetgums (Liquidambar styraciflua). The white rod in five of the photos is the reference scale raised to cavity height and used to measure entrance dimensions. Numbers beside arrows give the dimension in $\mathrm{cm}$.
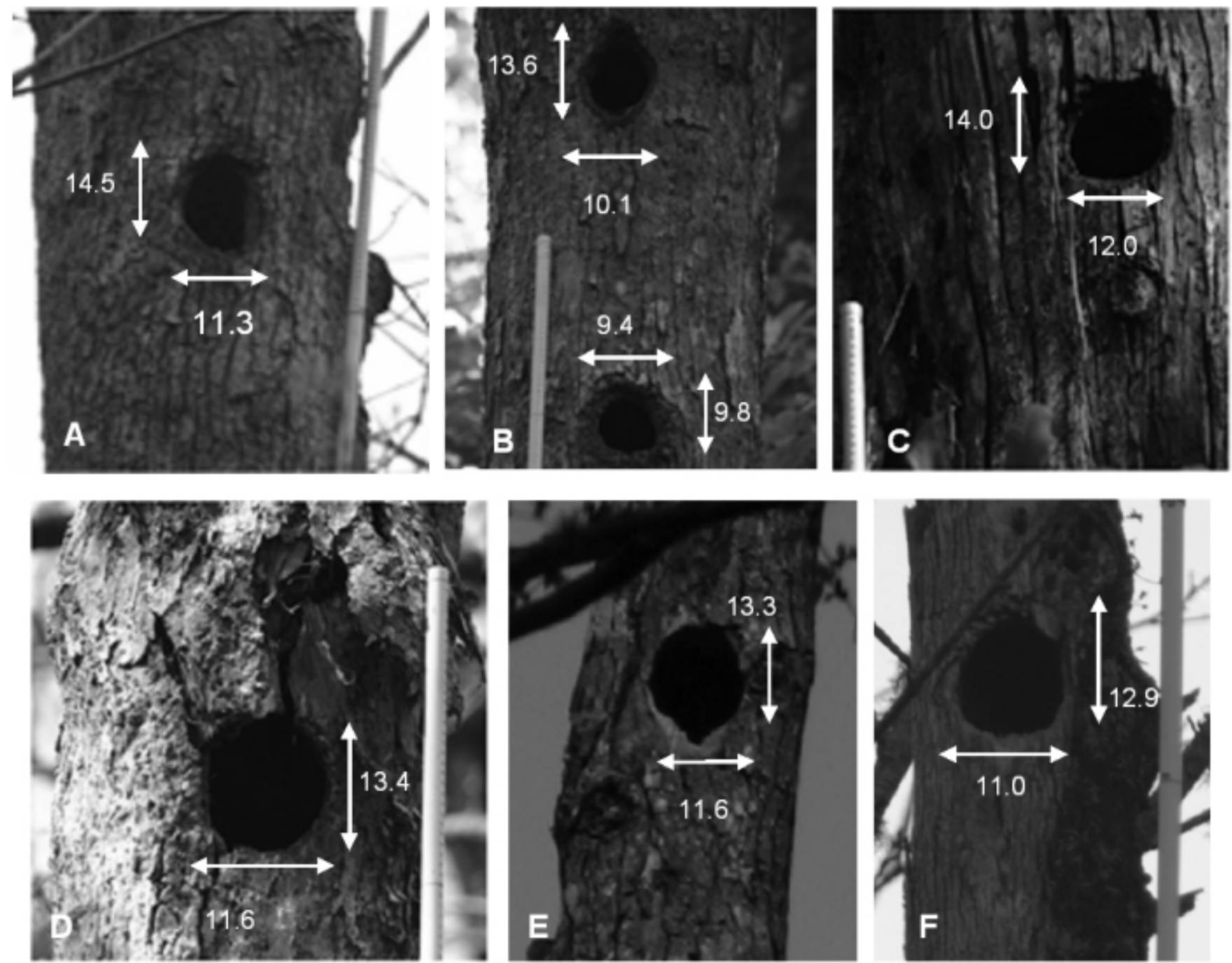
Fig. 3. Dimensions of nest cavity holes for large cavities along the Choctawhatchee River. Vertical diameter (A) and horizontal diameter (B) of cavity entrances for 131 nest cavities. Full ranges of published dimensions of Ivory-billed Woodpecker cavities (Tanner 1942) and Pileated Woodpecker cavities (Tanner 1942, Bull and Jackson 1995) are shown.
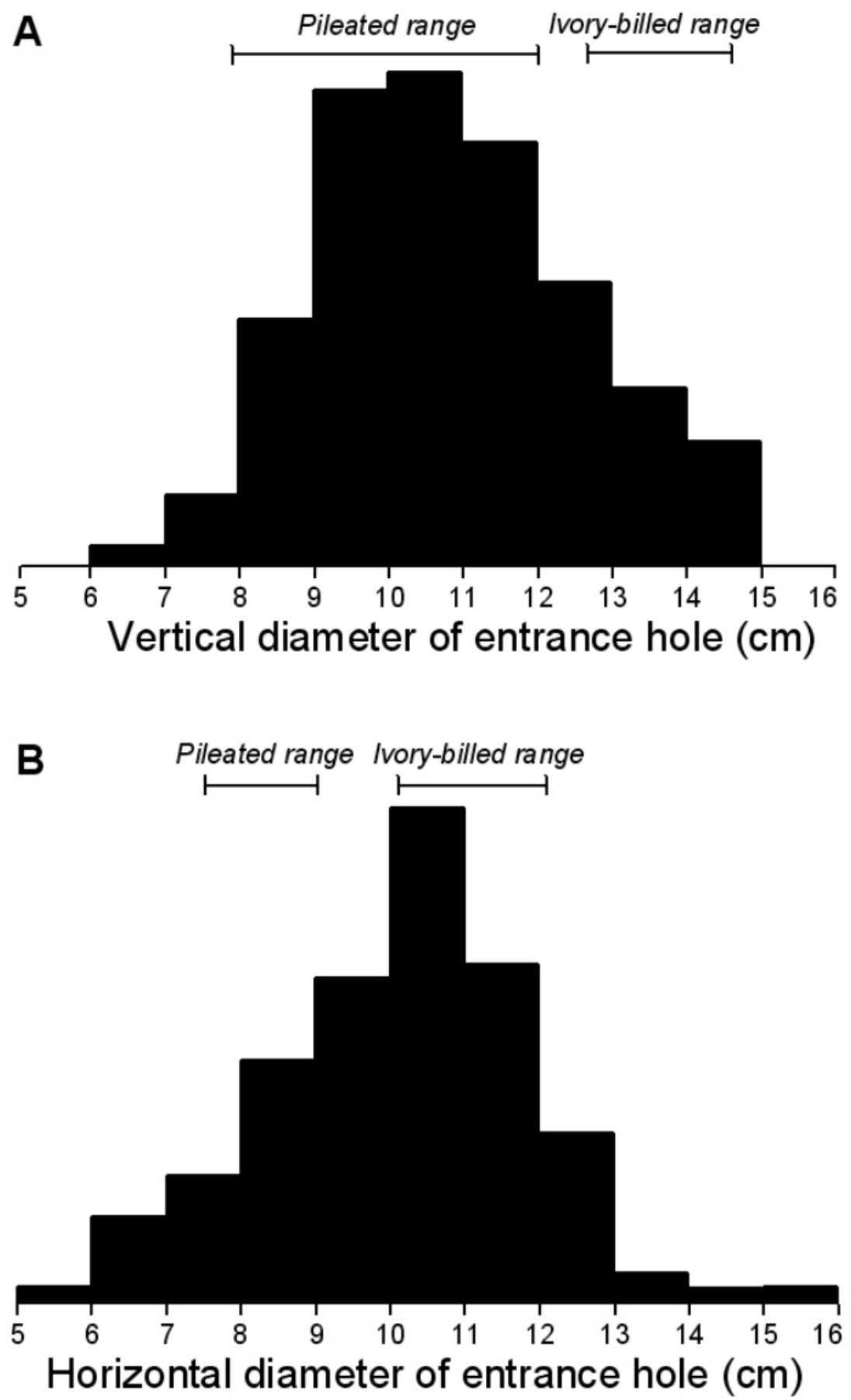
where Pileated Woodpeckers are common but where we have detected no Ivory-billed Woodpeckers. We measured the entrances of 21 cavities in Lee and Macon counties. Two of these cavities were active Pileated Woodpecker nests, and the remaining 19 shared a similar appearance. The average vertical diameter of cavities along the Choctawhatchee River $(10.8 \pm 0.2 \mathrm{~cm}, n=131)$ was significantly larger than the average vertical diameter of the 21 cavities in Lee and Macon counties $\left(8.5 \pm 0.4 \mathrm{~cm}, n=21\right.$; ANOVA: $\mathrm{F}_{1,151}=$ 30.2 , $\mathrm{p}<0.0001)$. Similarly, the average horizontal diameter of cavities along the Choctawhatchee River $(10.1 \pm 0.1 \mathrm{~cm})$ was significantly larger than the horizontal diameter of cavities in Lee and Macon counties $\left(7.9 \pm 0.3 \mathrm{~cm}\right.$; ANOVA: $\mathrm{F}_{1,151}=28.5, \mathrm{p}<$ $0.0001)$.

Many trees along the Choctawhatchee River had single cavities on their trunks, whereas others had two or more cavities stacked one above the other. Cavities occurred in both living and dead trees. Some cavity entrances appeared very fresh when we discovered them, with bright white wood around the perimeter of the cavity entrance and clearly visible bill marks. Bill marks, as distinct from the tooth marks of a gnawing mammal, could be seen through binoculars on several cavities, and we climbed to two large cavities and noted bill as opposed to tooth marks. We are confident that these cavities were cut into trees by birds and not enlarged by gnawing mammals. Most cavities in live trees appeared to have been excavated in previous years, with rims of scar tissue that diminished their original dimensions.

From December to April, we watched and video taped one or a few cavity entrances each evening and morning, but we never detected a woodpecker coming or going from a cavity.

\section{Foraging Sign}

According to Tanner, who watched Ivory-billed Woodpeckers feed in Louisiana in the 1930s, Ivorybilled Woodpeckers use their relatively flat, chisellike bills to scale tightly adhering bark from recently dead trees (Tanner 1942). Although Pileated Woodpeckers obtain food by scaling bark, they apparently do so primarily on trees with loosely adhering bark, and Tanner (1942) indicated that they do so less cleanly than Ivory-billed Woodpeckers (Tanner 1942). We found woodpecker feeding sign on numerous trees within our study area that fit Tanner's description for Ivory-billed Woodpeckers (Fig. 4).

Approximately $20 \%$ of scaled trees in our study area along the Choctawhatchee River had tightly adhering bark with adhesion values above those observed in swamp forests where Ivory-billed Woodpeckers have not been detected (Fig. 5). The mean adhesion of bark around foraging marks was significantly different among the four sites (ANOVA: $\left.\mathrm{F}_{3,542}=28.3, \mathrm{p}<0.0001\right)$ with significantly greater adhesion along the Choctawhatchee River than at the three other sites (Tukey-Kramer: $\mathrm{p}<0.05)$. There were no significant differences among sites in the mean diameter of trees measured (ANOVA: $\mathrm{F}_{3,542}=0.3, \mathrm{p}=0.66$; Table 1), and all four sites had grossly similar tree species composition. To evaluate whether the differences in bark adhesion might be due to differences in tree species composition, we compared bark adhesion among the four sites for sweetgum only. Again, we found that bark adhesion around woodpecker foraging marks was significantly different among the four sites (ANOVA: $F_{3,30}=3.26, p=0.03$ ) with greater adhesion along the Choctawhatchee River $(6.9 \pm 1.0 \mathrm{~kg}$ of force to lift bark, $n=23$ trees) than at the three other sites (Choctafaula Creek: $2.1 \pm 2.7$ $\mathrm{kg}, n=3$ trees; Sougahatchee Creek: $1.1 \pm 1.9 \mathrm{~kg}$, $n=6$ trees; Uphapee Creek: $2.2 \pm 2.7 \mathrm{~kg} ; n=2$ trees).

\section{DISCUSSION}

Our observations, acoustic encounters, audio recordings, measurements of cavities, and analysis of feeding sign provide evidence that Ivory-billed Woodpeckers may live along the Choctawhatchee River in the Florida panhandle. In a 1-year period from 21 May 2005 to 19 May 2006, members of our search team saw birds that we identified as Ivorybilled Woodpeckers 14 times. We heard sounds matching Ivory-billed Woodpecker kent calls and double knocks, and our listening stations recorded numerous putative kent calls and double knocks, including both sounds at the same recorder on the same day. At the location of our sightings and sound detections, we documented trees with very large cavities with dimensions exceeding the published range for Pileated Woodpecker cavities and exceeding sizes of cavities measured in a nearby area where Ivory-billed Woodpeckers are known not to occur. Also at this same location, and 
Fig. 4. Examples of the trees within our 500-ha study area with tightly adhering bark that has been scaled. Sweet gum (A, B, F) and spruce pine (D, E) commonly showed feeding sign. (C) A chisel on a small hardwood on which the bill of a foraging bird caught a thin section of the underlying sapwood and curled it. The arrows indicate the bore holes of insects revealed when bark was scaled away by a woodpecker.
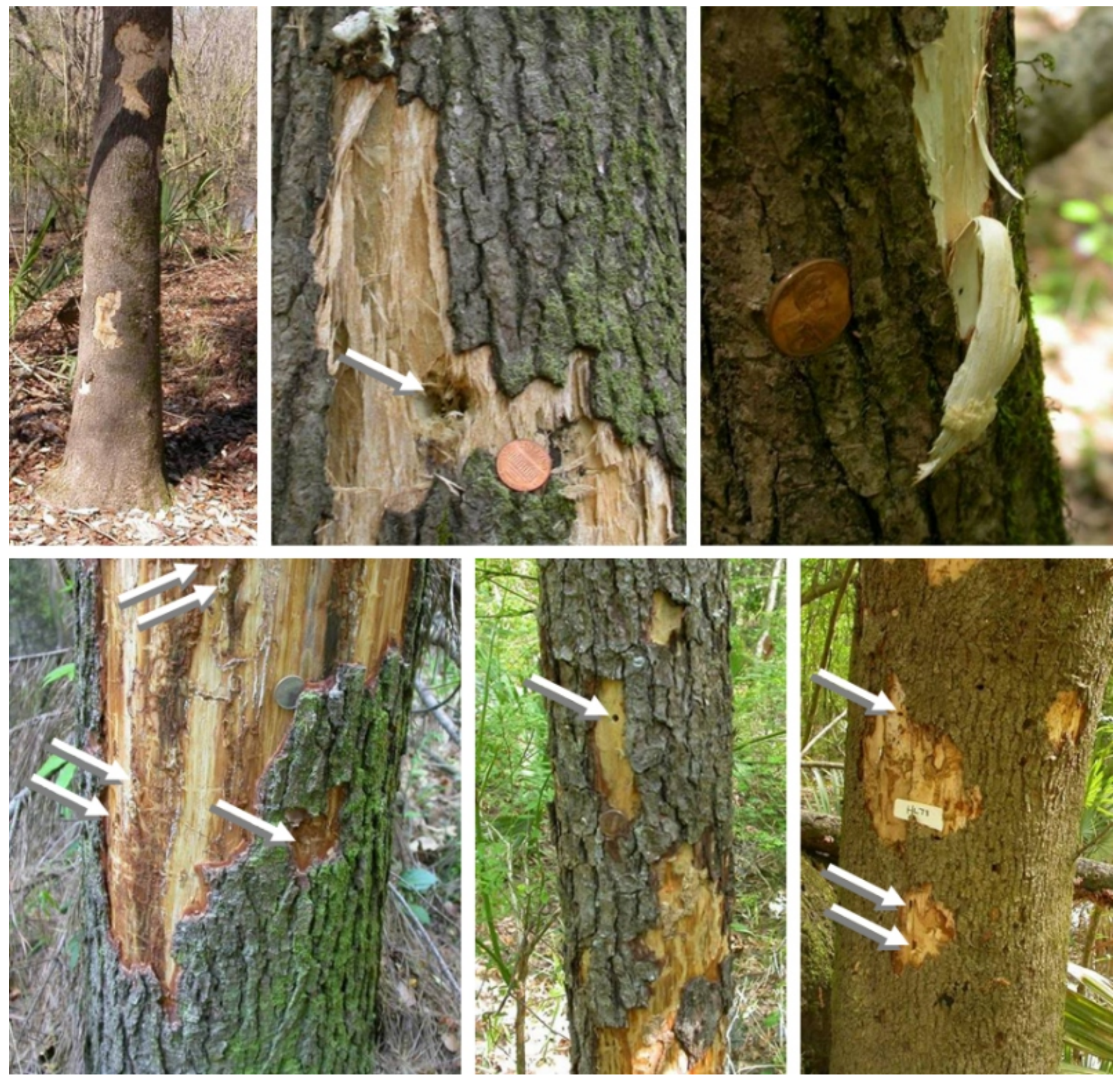
Fig. 5. Bark adhesion measurements from the forests along the Choctawhatchee River and comparison sites. Bark adhesion scores for woodpecker feeding trees along the Choctafaula Creek $(n=118$ trees; mean score $=1.28 \pm 1.48 \mathrm{~kg})(\mathrm{A})$, the Sougahatchee Creek $(n=117$ trees; mean score $=1.05 \pm 1.33 \mathrm{~kg})$ (B), and the Uphapee Creek ( $n=100$ trees; mean score $=1.22 \pm 1.79 \mathrm{~kg})(\mathrm{C})$ where Ivory-billed Woodpeckers were not detected. (D) Bark adhesion scores for woodpecker feeding sites along the Choctawhatchee River $(n=211$ trees; mean score $=4.76 \pm 6.85 \mathrm{~kg})$ where Ivory-billed Woodpeckers were detected.
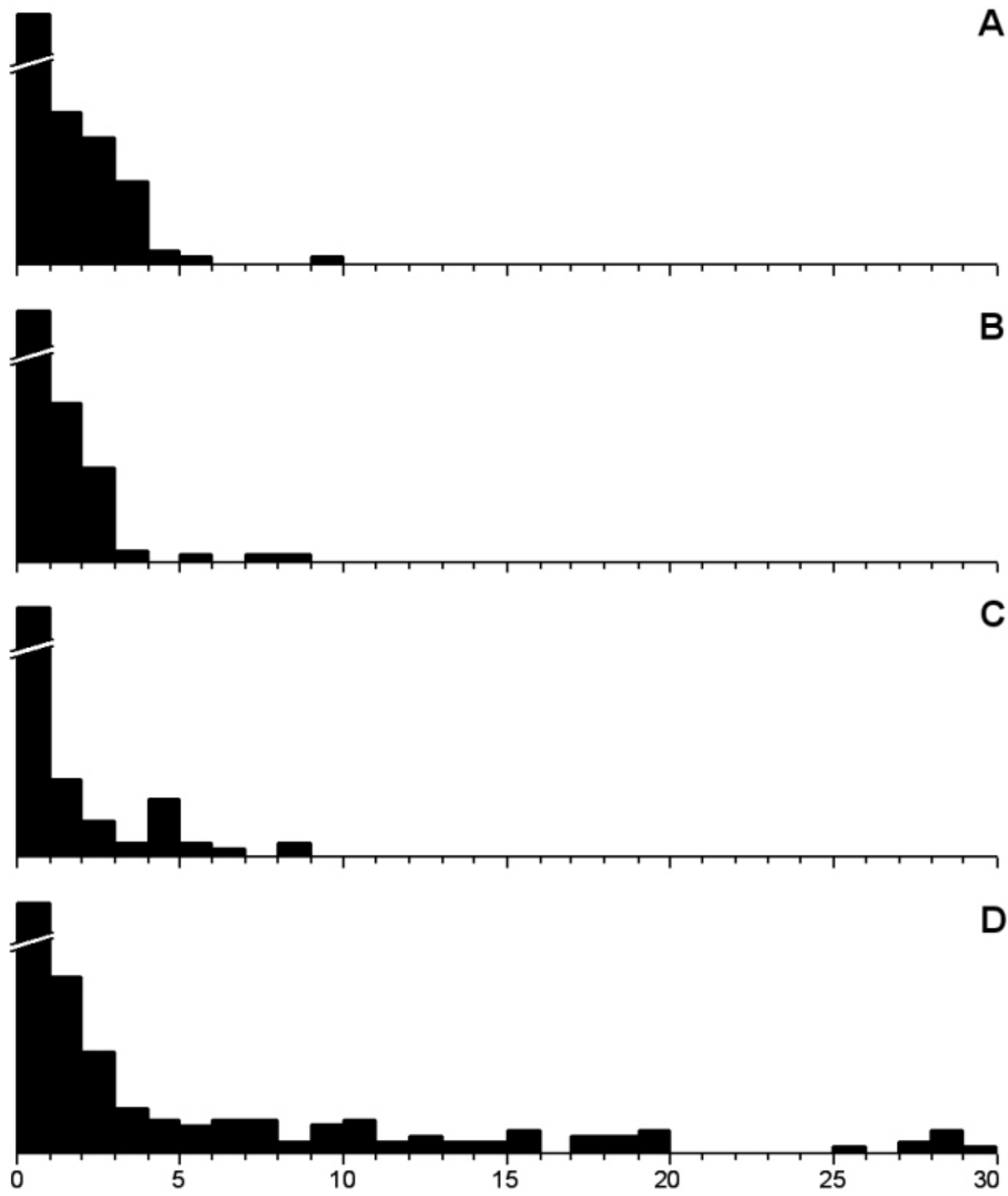

Bark adhesion ( $\mathrm{kg}$ of force to lift bark) 
Table 1. Bark adhesion and diameter at breast height $(\mathrm{DBH})$ for trees that showed signs of woodpecker feeding along the Choctawhatchee River where Ivory-billed Woodpeckers were detected, and at three comparison sites where Ivory-billed Woodpeckers were not detected.

\begin{tabular}{llllll}
\hline \hline Location & $\begin{array}{l}\text { No. trees } \\
\text { measured }\end{array}$ & $\begin{array}{l}\text { Mean bark adhesion } \\
(\mathbf{k g})\end{array}$ & Std.dev. Mean DBH $(\mathbf{c m}) *$ & Std. dev. \\
\hline Choctawhatchee River & 211 & 4.76 & 6.85 & 8.99 & 5.06 \\
Sougahatchee Creek & 117 & 1.05 & 1.33 & 8.65 & 5.09 \\
Uphapee Creek & 100 & 1.22 & 1.79 & 8.17 & 5.27 \\
Choctafaula Creek & 118 & 1.28 & 1.48 & 8.69 & 6.29
\end{tabular}

sometimes on the very trees with large cavities, we observed bark scaling unlike that seen in other southern bottomland forests. Any one of our lines of evidence could be dismissed as coincidental or a mistake, but together, these observations, collected by experienced ornithologists, suggest that Ivorybilled Woodpeckers may be present in the Florida panhandle. The persistence of Ivory-billed Woodpeckers will be established definitively only by a clear photograph or video image, a fresh feather, or perhaps genetic analysis of material from a nest or roost cavity, but the evidence presented here warrants an expanded search and protection of this bottomland forest habitat.

The swamp forests along the Choctawhatchee River constitute one of the largest tracts of mature forest in the southeastern U.S. This corridor of bottomland hardwood forest extends for about $60 \mathrm{~km}$, with an average width of about $2.5 \mathrm{~km}$. This forest was only selectively logged in the early $20^{\text {th }}$ century, and large areas suitable for Ivory-billed Woodpeckers likely persisted even through the decades of active logging. Although this river system lies near the center of the historic range of the Ivory-billed Woodpecker, no specimens are known from this region. A sight record from the Yellow River adjacent to Eglin Air Force Base in 1966, approximately $100 \mathrm{~km}$ east of our study area, and specimens and sight records from the Apalachicola River basin, approximately $100 \mathrm{~km}$ to the west of our study area, are the closest reports of Ivory-billed Woodpeckers to the Choctawhatchee River
(Jackson 2004) [ERRATUM]. A lack of museum specimens taken from the Choctawhatchee River suggests that Ivory-billed Woodpeckers escaped shooting by collectors in this river system. Much of this vast swamp forest is owned by the Northwest Florida Water Management District, a Florida state agency, so the prospects for preventing future logging and protecting birds in this area are good.

Walters and Crist (2006) recognized two problems inherent in any attempt to recover a population of Ivory-billed Woodpecker. First, Ivory-billed Woodpeckers will necessarily persist in small numbers, subjecting the species to the risk of extinction faced by all species reduced to small populations. Second, the Ivory-billed Woodpecker was driven to the brink of extinction primarily by loss of habitat. Unless large blocks of mature swamp forest can be restored, there is little hope for the recovery of this species. At this point, we do not know the number of Ivory-billed Woodpeckers that exist in the Choctawhatchee River basin or the specific habitat needs of Ivory-billed Woodpeckers in the Florida panhandle. Preliminary and cursory searches north and south of our study site have revealed foraging sign and large cavities that suggest Ivory-billed Woodpeckers might be widespread in this river system and might exist as more than a few isolated individuals. Large sections of this river basin appear to support old-growth swamp forest that may be suitable for Ivory-billed Woodpeckers. 
Future research related to the Ivory-billed Woodpecker in the Choctawhatchee River basin will focus on gathering definitive evidence for the existence of at least one bird, and searching for evidence of nesting Ivory-billed Woodpeckers. If definitive evidence is obtained, research will focus on estimating the size of the population and delimiting the portions of the Choctawhatchee River basin used by Ivory-billed Woodpeckers, and on searching similar river systems on the Florida panhandle, including the Escambia, Yellow, and Apalachicola rivers for evidence of other Ivorybilled Woodpeckers.

Responses to this article can be read online at:

http://www.ace-eco.org/voll/iss3/art2/responses/

\section{Acknowledgments:}

We thank S. Blake, D. Carr, C. Gresham, L. Hicks, W. Hood, M. Liu, and P. Mennill for assistance in the field, and S. Lippold, J. Mouland, S. Tremblay, and $K$. Winger for assistance with sound analyses. We thank J. Jackson, S. Doucet, T. Nudds, M.-A. Villard, J. Walters, and anonymous reviewers for excellent and very helpful comments on an earlier draft of the manuscript. Funding was provided by a Special Research Opportunity Grant and a Discovery Grant from the Natural Sciences and Engineering Research Council of Canada (NSERC) to DJM and by a discretionary grant from the College of Science and Mathematics at Auburn University to GEH.

Current affiliation for Tyler L. Hicks: Western State College

\section{LITERATURE CITED}

American Ornithologists' Union. 1983. Checklist of North American birds. Sixth Edition. Allen Press, Lawrence, Kansas, USA.

Bull, E. L., and J. A. Jackson. 1995. Pileated Woodpecker (Dryocopus pileatus). No. 148 in A. Poole and F. Gill, editors. The birds of North America. Birds of North America, Philadelphia, Pennsylvania, USA.
Charif, R. A., K. A. Cortopassi,H. K. Figueroa, J. W. Fitzpatrick, K. M. Fristrup, M. Lammertink, M. D. Luneau, Jr., M. E. Powers, and K. V. Rosenberg. 2005. Notes and double knocks from Arkansas. Science 309:1489.

Fitzpatrick J. W., M. Lammertink, M. D. Luneau, Jr., T. W. Gallagher, B. R. Harrison, G. M. Sparling, K. V. Rosenberg, R. W. Rohrbaugh, E. C. H. Swarthout, P. H. Wrege, S. B. Swarthout, M. S. Dantzker, R. A. Charif, T. R. Barksdale, J. V. Remsen, Jr., S. D. Simon, and D. Zollner. 2005. Ivory-billed Woodpecker (Campephilus principalis) persists in continental North America. Science 308:1460-1462.

Fitzpatrick, J. W., M. Lammertink, M. D. Luneau, Jr., T. W. Gallagher, and K. V. Rosenberg. 2006a. Response to comment on "Ivory-billed Woodpecker (Campephilus principalis) persists in continental North America." Science 311: $1555 b$.

Fitzpatrick J. W., M. Lammertink, M. D. Luneau, Jr., T. W. Gallagher, B. R. Harrison, G. M. Sparling, K. V. Rosenberg, R. W. Rohrbaugh, E. C.H. Swarthout, P. H. Wrege, S. B. Swarthout, M. S. Dantzker, R. A. Charif, T. R. Barksdale, J. V. Remsen, Jr., S. D. Simon, and D. Zollner. 2006b. Clarifications about current research on the status of Ivory-billed Woodpecker (Campephilus principalis) in Arkansas. Auk 123:587-593.

Gallagher, T. 2005. The grail bird: hot on the trail of the Ivory-billed Woodpecker. Houghton Mifflin, Boston, Massachussetts, USA.

Jackson, J. A. 2002. Ivory-billed Woodpecker (Campephilus principalis). No. 711 in A. Poole and F. Gill, editors. The birds of North America. Birds of North America, Philadelphia, Pennsylvania, USA.

Jackson, J. A. 2004. In search of the Ivory-billed Woodpecker. Smithsonian Books, Washington, D. C., USA.

Jackson, J. A. 2006a. In search of the Ivory-billed Woodpecker. Reprint Edition. Smithsonian Books, Washington, D.C., USA.

Jackson, J. A. 2006b. Ivory-billed Woodpecker (Campephilus principalis): hope, and the interfaces of science, conservation, and politics. Auk 123:1- 
15.

Lammertink, M. 1995. Status of the Ivory-billed Woodpecker (Campephilus principalis) in Cuba: almost certainly extinct. Cotinga 3:45-47.

Sibley, D. A., L. R. Bevier, M. A. Patten, and C. S. Elphick. 2006. Comment on "Ivory-billed Woodpecker (Campephilus principalis) persists in continental North America." Science 311:1555a.

Tanner, J. T. 1942. The Ivory-billed Woodpecker. Research Report Number 1. National Audubon Society, New York, New York, USA.

Tarvin, K. A., and G. E. Woolfenden. 1999, Blue Jay (Cyanocitta cristata). No. 469. in A. Poole and F. Gill, editors. The birds of North America. Birds of North America, Philadelphia, Pennsylvania, USA.

Walters, J. R., and E. L. Crist. 2006. Rediscovering the king of Woodpeckers: exploring the implications. Avian Conservation and Ecology -Écologie et Conservation des Oiseaux 1:1-6. 


\section{Appendix 1. Supplemental Materials.}

\section{Please click here to download file 'appendixl.pdf'.}


APPENDIX 2. A series of nine putative double knocks recorded on December 25, 2005 with a handheld videocamera, including two distant putative double knocks, five closer putative double knocks, and two more distant putative double knocks. TLH, who recorded these double knocks, and BWR, who stood next to him, though the sounds were coming from two birds in front of them in the forest but out of view.

File: appendix2.wav (658 KB .wav file).

To open this file you will require an audio or media application such as QuickTime, Windows Media Player, or iTunes. 
APPENDIX 3. A putative double knock recorded on January 5, 2006, at an automated listening station along the Choctawhatchee River.

File: appendix3.wav (193 KB .wav file).

To open this file you will require an audio or media application such as QuickTime, Windows Media Player, or iTunes. 
APPENDIX 4. A putative double knock recorded on January 7, 2006, at an automated listening station along the Choctawhatchee River.

File: appendix4.wav (118 KB .wav file).

To open this file you will require an audio or media application such as QuickTime, Windows Media Player, or iTunes. 
APPENDIX 5. A putative double knock recorded on February 6, 2006, at an automated listening station along the Choctawhatchee River.

File: appendix5.wav (84 KB .wav file).

To open this file you will require an audio or media application such as QuickTime, Windows Media Player, or iTunes. 
APPENDIX 6. A putative double knock recorded on February 24, 2006, at an automated listening station along the Choctawhatchee River.

File: appendix6.wav (239 KB .wav file).

To open this file you will require an audio or media application such as QuickTime, Windows Media Player, or iTunes. 
APPENDIX 7. A putative kent call recorded on February 9, 2006, at an automated listening station along the Choctawhatchee River.

File: appendix7.wav (142 KB .wav file).

To open this file you will require an audio or media application such as QuickTime, Windows Media Player, or iTunes. 
APPENDIX 8. A putative kent call recorded on March 14, 2006, at an automated listening station along the Choctawhatchee River.

File: appendix8.wav (121 KB .wav file).

To open this file you will require an audio or media application such as QuickTime, Windows Media Player, or iTunes. 
APPENDIX 9. A series of putative kent calls recorded on March 15, 2006, at an automated listening station along the Choctawhatchee River.

File: appendix9.wav (229 KB .wav file).

To open this file you will require an audio or media application such as QuickTime, Windows Media Player, or iTunes. 
APPENDIX 10. Another series of putative kent calls recorded on March 15, 2006, at an automated listening station along the Choctawhatchee River.

File: appendix10.wav (593 KB .wav file).

To open this file you will require an audio or media application such as QuickTime, Windows Media Player, or iTunes. 
APPENDIX 11. Nine double knocks of a Pale-billed Woodpecker (Campephilus guatemalensis) recorded on May 12, 2006, in Santa Rosa National Park in the Guanacaste Conservation Area of northwest Costa Rica. Recorded by DJM with a Sennheiser MKH70 directional shotgun microphone. All double knocks were produced by the same bird on different parts of one tree, demonstrating the variation in the quality of double knock sounds. The spaces between subsequent double knocks in this sound file have been trimmed.

File: appendix11.wav (1551 KB .wav file).

To open this file you will require an audio or media application such as QuickTime, Windows Media Player, or iTunes. 